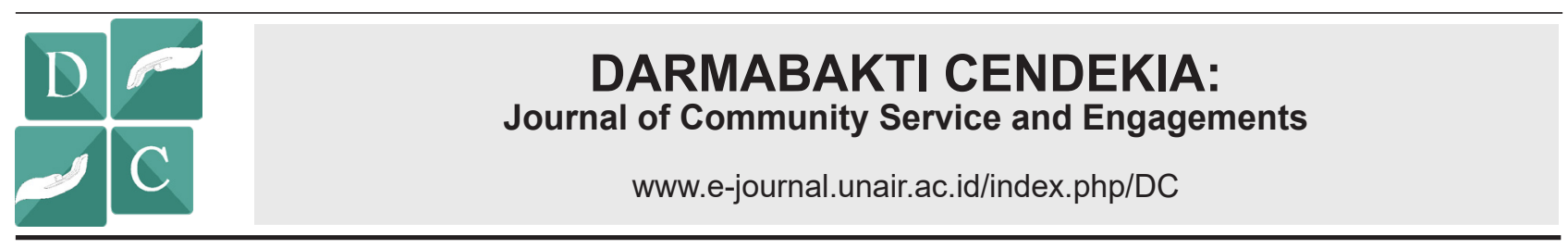

\title{
PUBLIC AWARENESS ABOUT SYMPTOMS AND PREVENTION OF COVID-19 IN BENOWO, SURABAYA
}

\author{
KESADARAN MASYARAKAT TENTANG GEJALA DAN PENCEGAHAN \\ COVID-19 DI KECAMATAN BENOWO SURABAYA \\ Health
}

Scope:

Dwi Wahyu Indriati回 Diyantord圆 Anita Kurniati回, Aliyah Siti Sundar国
Rizka Oktarianti Ainun Jariah回 Nur Septia Handayan
Study Program of Medical Laboratory Technology, Faculty of Vocational Studies, Universitas Airlangga, Surabaya-Indonesia

\section{A B S T R A C T}

Background: Since its first report, COVID-19 has remained a major threat worldwide. Various attempts were made to treat and prevent further transmission of COVID-19. In Indonesia, although the first case was reported nearly five months after the first case in Wuhan, the transmission was the fastest among Southeast Asian countries. Several efforts have been made to prevent further transmission. Objective: Our community services program aimed to assess the public understanding of COVID-19 symptoms and the application of SHE (Self and Environmental Health) as a form of COVID-19 prevention. Method: We conducted counseling using a door-to-door method to increase the understanding of SHE as a form of COVID-19 prevention and then at the end of the visit, a questionnaire was given to measure the understanding of symptoms and prevention COVID-19 transmission. Results: After conducted the door-to-door counselling in Kandangan district, it is known that the public understanding of the symptoms and ways of preventing COVID-19 is quite good. The method of prevention that is understood by the public includes using masks, diligently wash hands, and maintain social distance in gathering. However, there are still people who do not understand (31.13\%) that increasing their immune system by consuming nutritious and balanced food and exercise can also be used to prevent the transmission of COVID-19. Because a good immune system can prevent individuals from infection with pathogens such as COVID-19. Conclusion: The community has sufficient understanding of the symptoms and ways of preventing COVID-19 so that it is expected it can reduce the transmission of COVID-19 in Benowo District, Surabaya.

\section{A B S T R A K}

Latar belakang: Sejak pertama kali dilaporkan, COVID-19 tetap menjadi ancaman utama di seluruh dunia. Berbagai upaya dilakukan untuk mengobati dan mencegah penularan COVID-19 lebih lanjut. Di Indonesia, meskipun kasus pertama dilaporkan hampir lima bulan setelah kasus pertama di Wuhan, penularannya tercepat di antara negara-negara Asia Tenggara. Beberapa upaya telah dilakukan untuk mencegah penularan lebih lanjut. Tujuan: mengetahui pemahaman masyarakat di Kecamatan Benowo akan gejala COVID-19 serta penerapan SHE (Self and Environemntal Health) sebagai bentuk pencegahan transmisi COVID-19. Metode: Dengan penyuluhan door to door untuk meningkatkan pemahaman tentang SHE sebagai bentuk pencegahan COVID-19 kemudian di akhir kunjungan diberikan kuesioner untuk mengukur pemahaman mengenai gejala dan langkah-langkah pencegahan transmisi COVID-19. Hasil: Setelah dilakukan penyuluhan secara door to door di Kecamatan kandangan, diketahui bahwa pemahaman masyarakat mengenai gejala dan cara pencegahan COVID-19 sudah cukup baik. Cara pencegahan yang dipahami masyarakat adalah penggunaan masker, mencuci tangan serta perlunya menjaga jarak (social distancing) saat berada di kerumunan. Namun masih terdapat masyarakat yang belum memahami (31.13\%) bahwa peningkatan sistem imun dengan mengkonsumsi makanan yang bergizi seimbang serta olah raga dapat juga digunakan untuk mencegah penularan COVID-19. Dikarenakan dengan sistem imun yang baik maka dapat menghindarkan individu dari infeksi patogen seperti halnya COVID-19. Kesimpulan: Masyarakat telah memiliki pemahaman yang cukup akan gejala dan cara pencegahan COVID-19 sehingga diharapkan dapat menekan transmisi COVID-19 di Kecamatan Benowo, Surabaya

\author{
A R T I C LE INFO \\ Received 14 December 2020 \\ Revised 3 September 2021 \\ Accepted 19 October 2021 \\ Online 10 November 2021 \\ *Correspondence (Korespondensi): \\ Dwi Wahyu Indriati \\ E-mail: \\ dwiwahyu.indriati@vokasi.unair. \\ ac.id
}

\section{Keywords:}

COVID-19; Immunity; Masks;

Hand wash; Social distancing;

Prevention
Kata kunci:

COVID-19; Imunitas; Gejala; Masker; Mencuci tangan; Menjaga jarak; Pencegahan 


\section{PENDAHULUAN}

Kasus pneumonia misterius yang sumber penularannya belum diketahui dilaporkan di Wuhan, Provinsi Hubei pada akhir Desember 2019. Kasus pertama ini dikaitkan dengan keberadaan pasar ikan di Wuhan (Rothan \& Byrareddy, 2020). Pada bulan Desember 2019 tersebut sudah dilaporkan terdapat lima pasien yang dirawat dengan Acute Respiratory Distress Syndrome (ARDS) [Ren et al., 2020). Kemudian sejak akhir Desember hingga 3 Januari 2020 terjadi peningkatan pesat kasus sebanyak 44 kasus. Kasus penyakit kemudian dilaporkan pada bulan Januari di berbagai provinsi lain di China, Thailand, Jepang, dan Korea Selatan (Huang et al., 2020)

Etiologi coronavirus baru ditemukan pada sampel yang diperoleh dari pasien (Ren et al., 2020). Di awal kemunculan penyakit ini dikenal dengan 2019 novel coronavirus (2019- nCoV), sebelum WHO kemudian memberikan penamaan baru pada 11 Februari 2020 yaitu Coronavirus Disease (COVID-19). Penyakit COVID-19 ini disebabkan oleh virus Severe Acute Respiratory Syndrome Coronavirus-2 (SARS-CoV-2) (WHO, 2020a) Virus ini dapat menular dari individu satu ke individu lainnya dan menyebar secara luas di China dan lebih dari 190 negara. Hingga pada saat WHO mengumumkan COVID-19 sebagai pandemik tercatat 634.835 kasus dan 33.106 jumlah kematian di seluruh dunia. Hingga tanggal 30 Maret 2020, terdapat 693.224 kasus dan 33.106 kematian di seluruh dunia. Benua Eropa dan Amerika Utara menjadi pusat pandemi COVID-19 selanjutnya dengan kasus dan kematian sudah melampaui China. Amerika Serikat menduduki peringkat pertama dengan kasus COVID-19 terbanyak dengan penambahan kasus baru sebanyak 19.332 kasus pada tanggal 30 Maret 2020 disusul oleh Spanyol dengan 6.549 kasus baru. Italia memiliki tingkat mortalitas paling tinggi di dunia, yaitu 11,3\% (WHO, 2020b).

Dua kasus COVID-19 pertama dilaporkan di_lndonesia pada tanggal 2 Maret 2020 (WHO, 2020C). Sedangkan data pada 31 Maret 2020 telah menunjukkan kasus terkonfirmasi berjumlah 1.528 kasus dan 136 kasus kematian (Kementerian Kesehatan Republik Indonesia, 2020). Tingkat mortalitas COVID-19 di Indoonesia merupakan yang tertinggi di Asia Tenggara yakni sebesar 8,9 (WHO, 2020d, 2020b)

Berdasarkan data yang sudah ada, faktor risiko dari infeksi SARS-CoV-2 adalah penyakit komorbid hipertensi dan diabetes melitus, jenis kelamin laki-laki, dan perokok aktif. Penderita lakilaki ditemukan lebih banyak dibandingkan dengan perempuan terkait dengan prevalensi perokok aktif yang lebih tinggi pada laki-laki. Pada individu yang merokok, memiliki hipertensi, dan diabetes melitus, diduga terdapat peningkatan ekspresi reseptor ACE2 (Cai, 2020; Fang et al., 2020) Studi yang lain menduga pengguna penghambat $A C E$ (ACE-I) atau angiotensin receptor blocker (ARB) berisiko mengalami COVID-19 yang lebih berat (Diaz, 2020). Studi meta-analisis yang dilakukan oleh Yang et al., (2020) menunjukkan bahwa pasien COVID-19 dengan riwayat penyakit sistem respirasi akan cenderung memiliki manifestasi klinis yang lebih parah. Beberapa faktor risiko lain yang menyebabkan kasus penularan yang tinggi berdasarkan data yang diperoleh dari Centers for Disease Control and Prevention (CDC) adalah kontak erat, termasuk tinggal satu rumah dengan pasien COVID-19 dan riwayat perjalanan ke area terjangkit. Berada dalam satu lingkungan namun tidak kontak dekat (dalam radius 2 meter) dianggap sebagai risiko rendah (CDC, 2020a). Tenaga medis merupakan salah satu populasi yang berisiko tinggi tertular. Di Italia, sekitar 9\% kasus COVID-19 adalah tenaga medis (ICN, 2020). Di China, lebih dari 3.300 tenaga medis juga terinfeksi, dengan mortalitas sebesar 0,6\% (Wang et al., 2020).

Dikarenakan metode pengobatan untuk COVID-19 belum ditemukan maka pencegahan transmisi dapat dijadikan metode untuk mengurangi jumlah kasus infeksi. Beberapa metode pencegahan yang disarankan diantaranya adalah menggunakan masker, menjaga jarak, menghindari kerumunan dan tempat-tempat dengan ventilasi buruk, mencuci tangan, menutupi mulut dengan siku ketika batuk atau bersin, membersihkan dan mendesinfeksi setiap pernukaan seperti gagang pintu (CDC, 2020b). Oleh karena itu kegiatan pengabdian masyarakat ini difokuskan untuk melihat pemahaman masyarakat kecamatan Benowo terhadap cara pencegahan COVID-19, mengingat Surabaya juga merupakan kota dengan tingkat infeksi COVID-19 yang cukup tinggi di Jawa Timur.

\section{METODE}

Dalam kegiatan Pengabdian Kepada Mlasyarakat ini akan dilakukan kepada masyarakat sekitar di wilayah Kecamatan Benowo. Metode yang digunakan dalam pelaksanaan kegiatan pengabdian kepada masyarakat ini dilakukan disesuaikan dengan keadaan pandemi COVID-19 meliputi tahap pembinaan dan tahap evaluasi dan pemantauan. Pada tahap pembinaan ini dilaksanakan dengan mengundang masyarakat melalui door to door dan brosur yang disampaikan ke tiap anggota dasawisma yang ada di kelurahan kandangan. Adapun materi pembinaan yang disampaikan meliputi: Pengenalan tanda-tanda 
penyakit COVID-19 ; Pencegahan COVID-19 selain pembagian brosur juga dibagikan hand sanitizer, masker dan sabun cuci tangan untuk mendukung program pencegahan COVID-19. Setelah pembagian kit pencegahan COVID-19 dilakukan tahapan evaluasi dan pemantuan. Beberapa metode penilaian dilakukan untuk memastikan kegiatan pengabdian kepada masyarakat ini dapat dijalankan dengan baik dan optimal, diantaranya: a. Post-test. Masyarakat yang menjadi peserta akan diberikan post-test untuk mengetahui pemahaman masyarakat dalam menerima informasi yang diberikan melalui kegiatan penyuluhan. Kuesioner yang digunakan terdiri dari 3 pertanyaan meliputi pemahaman gejala klinis, prosedur pencegahan, dan teknik-teknik pencegahan infeksi COVID-19; b. Observasi-Demonstrasi. Masyarakat harus mempraktikkan cara pola hidup sehat untuk mengetahui kemampuan masyarakat dalam menerapkan teknologi tepat guna.

\section{HASIL DAN PEMBAHASAN}

Usaha konkrit yang dapat dilakukan untuk mengurangi kasus COVID-19 adalah dengan menerapkan proteksi atau perlindungan dan pencegahan sesuai protokol kesehatan. Penggunaan masker menjadi salah satu cara untuk melindungi individu dari individu yang positif COVID-19. Masyarakat perlu diedukasi pentingnya penggunaan masker ini, dikarenakan masih banyak di antara anggota masyarakat yang masih menganggap sepele anjuran penggunaan masker ini. Bahan masker yang tepat untuk dapat memberikan perlindungan COVID-19 juga menjadi salah satu edukasi yang penting di tengah masyarakat. Penggunaan face shield juga sering ditemukan di masyarakat, namun penggunaan masker dan face shield lebih dianjurkan dibandingkan hanya menggunakan face shield saja. Tidak hanya penggunaan masker, merubah kebiasaan masyarakat untuk rajin cuci tangan juga memerlukan edukasi yang tepat. Mencuci tangan yang benar dilakukan dengan sabun yang dapat membunuh kuman-kuman yang ada di tangan termasuk salah satunya adalah COVID-19, di mana COVID-19 ini merusak virus memiliki envelope yang dapat diinaktivasi atau rusak dengan penggunaan sabun. Selain cuci tangan dengan sabun, penggunaan hand sanitizer juga dapat dilakukan di area yang tidak memungkinkan untuk melakukan cuci tangan. Sehingga untuk kebiasaan baru masyarakat perlu ditambahkan unntuk selalu membawa masker dan hand sanitizer di setiap kegiatan yang dilakukan di luar rumah.

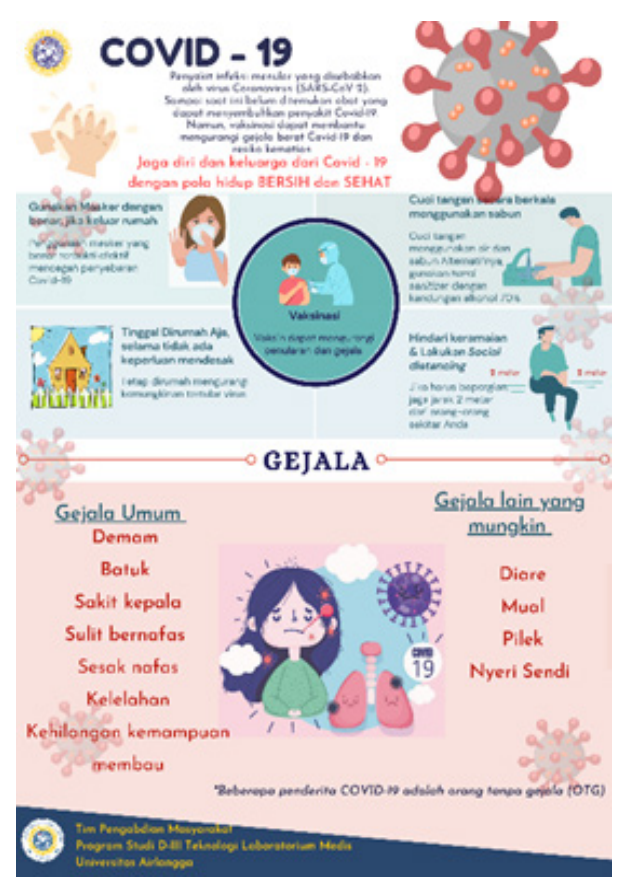

Gambar 1. Brosur yang disampaikan pada kegiatan pengabdian masyarakat di Kelurahan Kandangan

Masyarakat juga diedukasi untuk menghindari keramaian dan melakukan social distancing terutama pada area-area kantor, pasar dll. Sehingga dengan melakukan social distancing atau memberikan jarak di setiap keramaian akan turut menurunkan risiko penularan COVID-19. Selain itu bagi warga yang merasakan gejala COVID-19, kami sarankan untuk segera mengunjungi fasilitas Kesehatan terdekat untuk memperoleh perawatan ataupun untuk melakukan test COVID-19. Pada warga yang pernah berinteraksi dengan individu yang positif COVID-19 juga dihimbau untuk melakukan test COVID-19, serta isolasi mandiri jika diketahui positif tetapi tidak menunjukkan gejala klinis COVID-19. Pencegahan COVID-19 juga dapat dilakukan dengan selalu menjaga sistem imun tubuh agar siap menghadapi infeksi oleh kuman dengan makan makanan bergizi serta rajin berolahraga. Menjaga kesahatan jasmani dan rohani juga menjadi penting sehingga tidak mudah terinfeksi oleh kuman penyakit. Bagi warga yang telah terinfeksi menjaga sistem imunitas tubuh ini juga penting sehingga diharapkan dapat meningkatkan probabilitas untuk sembuh lebih cepat. Selanjutnya setelah mengetahui cara pencegahan COVID-19, kami memberikan kuesioner (Gambar 2) untuk mengetahui tingkat pemahaman masyarakat terhadap prosedur pencegahan COVID-19 yang telah disampaikan baik melalui brosur maupun pertemuan door to door dengan perwakilan tiap dasawisma yang ada di Kelurahan Kandangan, Kecamatan Benowo, Surabaya. Hal ini menjadi perlu dilakukan untuk 
mengetahui apakah kesadaran masyarakat sekitar setelah kegiatan pengabdian masyarakat ini menjadi meningkat atau tidak mengalami perubahan (Gambar 3). Dari hasil kuesioner (106 responden) yang diberikan sebagian besar masyarakat mengetahui gejala-gejala klinis yang ditimbulkan oleh infeksi COVID-19 $(85.85 \%)$ serta prosedur pencegahannya (95.28\%) (Tabel 1). Sedangkan untuk teknik pencegahan InfeksI COVID-19 ini sebagian besar memahami dengan pemakaian masker dapat mencegah transmisi COVID-19 (88.68\%). Selain penggunaan masker, dengan rajin mencuci tangan dan menjaga jarak saat di keramaian juga sudah dipahami sebagai cara untuk mencegah penularan COVID-19. Tetapi sebagian responden masih belum mengetahui bahwa dengan meningkatkan imunitas melalui makanan bergizi dan olahraga juga dapat secara tidak langssung mencegah penularan COVID-19 (68.87\%) (Tabel 1). Bisa disimpulkan bahwa untuk pemahaman masyarakat juga perlu ditingkatkan dengan sosialisasi kembali bahwa meningkatkan sistem imun ini juga berperan penting dalam pencegahan penyakit infeksi tidak hanya oleh COVID-19 tetapi bisa juga mikroorganisme penyebab penyakit lainnya.

\section{KUISIONER COVID-19}

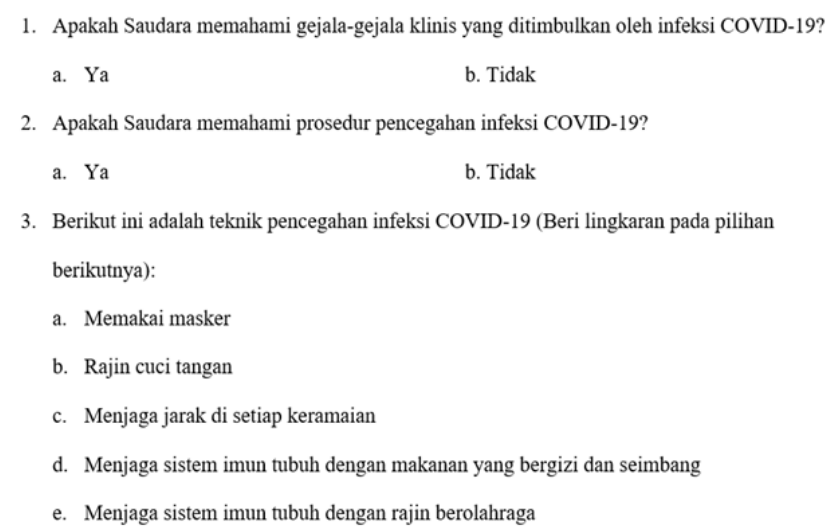

Gambar 2. Kuesioner pemahaman terkait COVID-19 pada masyarakat di Kelurahan Kandangan

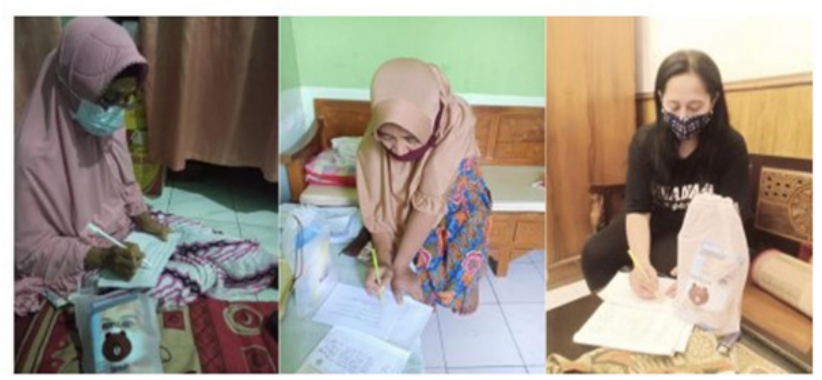

Gambar 3. Pengisian kuesioner pemahaman teknik pencegahan infeksi COVID-19
Tabel 1. Hasil kuesioner mengenai pemahaman COVID-19

\begin{tabular}{|c|c|c|c|}
\hline $\begin{array}{l}\text { Variabel } \\
\text { Kuesioner }\end{array}$ & Kategori & $\begin{array}{c}\text { Jumlah } \\
\text { Koresponden }\end{array}$ & $\%$ \\
\hline \multirow{2}{*}{$\begin{array}{l}\text { Pemahaman } \\
\text { Gejala Klinis }\end{array}$} & $\mathrm{Ya}$ & 106 & 85.85 \\
\hline & Tidak & 106 & 14.15 \\
\hline \multirow{2}{*}{$\begin{array}{l}\text { Pemahaman } \\
\text { Pencegahan } \\
\text { Infeksi }\end{array}$} & $\mathrm{Ya}$ & 106 & 95.28 \\
\hline & Tidak & 106 & 4.72 \\
\hline \multirow{5}{*}{$\begin{array}{l}\text { Teknik } \\
\text { Pencegahan } \\
\text { Infeksi }\end{array}$} & $\begin{array}{l}\text { Memakai } \\
\text { masker }\end{array}$ & 106 & 88.68 \\
\hline & $\begin{array}{l}\text { Rajin cuci } \\
\text { tangan }\end{array}$ & 106 & 69.81 \\
\hline & $\begin{array}{l}\text { Menjaga jarak } \\
\text { di setiap } \\
\text { keramaian }\end{array}$ & 106 & 74.53 \\
\hline & $\begin{array}{l}\text { Menjaga } \\
\text { sistem imun } \\
\text { tubuh dengan } \\
\text { makanan yang } \\
\text { bergizi dan } \\
\text { seimbang }\end{array}$ & 106 & 68.87 \\
\hline & $\begin{array}{l}\text { Menjaga sistem } \\
\text { imun tubuh } \\
\text { dengan rajin } \\
\text { berolahraga }\end{array}$ & 106 & 68.87 \\
\hline
\end{tabular}

\section{KESIMPULAN DAN SARAN}

Salah satu bentuk usaha yang dapat dilakukan untuk menekan jumlah penderita akibat COVID-19 adalah dengan mengedukasi masyarakat untuk mencegah resiko penularan COVID-19seperti dengan penerapan pemakaian masker, rajin cuci tangan atau menggunakan hand sanitizer serta adanya social distancing di tengah masyarakat. Pemahaman masyarakat mengenai tiga cara pencegahan ini sudah sangat baik. Selain itu masyarakat juga perlu diberikan sosialisasi mengenai pentingnya menjaga sistem imun agar tidak mudah terserang berbagai macam patogen seperti salah satunya adalah COVID-19.

\section{UCAPAN TERIMA KASIH}

Terima kasih kepada pada ketua dasawisma yang ada di Kelurahan Kandangan Kecamatan Benowo Surabaya, Bapak Lurah Kandangan dan semua pihak yang membantu terselenggaranya kegiatan pengabdian masyarakat ini. Pada bagian akhir kami menyatakan. Penulis menyatakan tidak ada konflik kepentingan dengan pihak-pihak yang terkait dalam kegiatan pengabdian kepada masyarakat ini. 


\section{DAFTAR PUSTAKA}

Cai, H., 2020. Sex difference and smoking predisposition in patients with COVID-19. Lancet. Respir. Med. Vol. 8(4), ezo.

CDC, 2020a. Interim US Guidance for Risk Assessment and Public Health Management of Persons with Potential Coronavirus Disease 2019 (COVID-19) Exposures: Geographic Risk and Contacts of Laboratory-confirmed Cases [WWW Document]. URL https:// www.cdc.gov/coronavirus/2019-ncov/php/ riskassessment.html. (diakses 9.16.21).

CDC, 2020b. Protect Yourself [WWW Document]. URL https://www.cdc.gov/coronavirus/2019ncov/prevent-getting-sick/prevention.html (diakses 9.16.21).

Diaz, J.H., 2020. Hypothesis: angiotensinconverting enzyme inhibitors and angiotensin receptor blockers may increase the risk of severe COVID-19. J. Travel Med.

Fang, L., Karakiulakis, G., Roth, M., 2020. Are patients with hypertension and diabetes mellitus at increased risk for COVID-19 infection? Lancet. Respir. Med. Vol. 8(4), e21.

Huang, C., Wang, Y., Li, X., Ren, L., Zhao, J., Hu, Y., Zhang, L., Fan, G., Xu, J., Gu, X., Cheng, Z., Yu, T., Xia, J., Wei, Y., Wu, W., Xie, X., Yin, W., Li, H., Liu, M., Xiao, Y., Gao, H., Guo, L., Xie, J., Wang, G., Jiang, R., Gao, Z., Jin, Q., Wang, J., Cao, B., 2020. Clinical features of patients infected with 2019 novel coronavirus in Wuhan, China. Lancet Vol. 395 (10223), Pp. 497-506.

Kementerian Kesehatan Republik Indonesia, 2020. Info Infeksi Emerging Kementerian Kesehatan RI [WWW Document]. URL https:// infeksiemerging.kemkes.go.id/

Ren, L.L., Wang, Y.M., Wu, Z.Q., Xiang, Z.C., Guo, L., Xu, T., Jiang, Y.Z., Xiong, Y., Li, Y.J., Li, X.W., Li, H., Fan, G.H., Gu, X.Y., Xiao, Y., Gao, H., Xu,
J.Y., Yang, F., Wang, X.M., Wu, C., Chen, L., Liu, Y.W., Liu, B., Yang, J., Wang, X.R., Dong, J., Li, L., Huang, C.L., Zhao, J.P., Hu, Y., Cheng, Z.S., Liu, L.L., Qian, Z.H., Qin, C., Jin, Q., Cao, B., Wang, J.W., 2020. Identification of a novel coronavirus causing severe pneumonia in human: a descriptive study. Chin. Med. J. (Engl). Vol. 133(9), Pp. 1015-1024.

Rothan, H.A., Byrareddy, S.N., 2020. The epidemiology and pathogenesis of coronavirus disease (COVID-19) outbreak. J. Autoimmun. Vol. 109, Pp. 102433.

Wang, J., Zhou, M., Liu, F., 2020. Exploring the reasons for healthcare workers infected with novel coronavirus disease 2019 (COVID-19) in China. J. Hosp. Infect. Vol. 105(1), Pp. 100-101.

WHO, 2020a. Naming the coronavirus disease (COVID-19) and the virus that causes it [WWW Document]. URL https://www.who.int/ docs/default-source/coronaviruse/situationreports/20200330- sitrep-70-COVID-19. pdf?sfvrsn=7eofezf8_2 (diakses 9.16.21).

WHO, 2020b. Coronavirus disease 2019 (COVID-19) Situation Report - 70 [WWW Document]. URL https://www.who.int/ docs/default-source/ coronaviruse/situation-reports/20200330sitrep-70-COVID-19.pdf?sfvrsn=7eofe3f8_2 (diakses 9.16.21).

WHO, 2020C. Situation Report - 42 [WWW Document]. URL https://www.who.int/ docs/default-source/ coronaviruse/situationreports/20200302-sitrep-42-covid-19. pdf?sfvrsn=224c1add_2.https://www.who.int/ docs/default-source/ ${ }^{-}$coronaviruse/situationreports/20200302-sitrep-42-covid-19. pdf?.sfvrsn=224c1add 2 (diakses 9.16.21).

WHO, 2020d. Novel Coronavirus (2019-nCoV) Situation Report - 54 [WWW Document]. URL 20200314-sitrep-54-covid-19.pdf (who.int) (diakses 9.16.21). 